\title{
CHALLENGES FACED IN MODERN QUALITY INSPECTION
}

\author{
Stanisław Borkowski, Krzysztof Knop \\ Czestochowa University of Technology, Institute of Production Engineering, Poland
}

Corresponding author:

Krzysztof Knop

Czestochowa University of Technology

Institute of Production Engineering

Armii Krajowej 19B, 42-200 Czestochowa, Poland

phone: (+48) 343250367

e-mail:kknop@poczta.fm

Received: 11 December 2015

Accepted: 22 August 2016

\section{Abstract}

Point of view, preferences and priorities of quality inspection in modern production systems have changed. Quality inspection in its activities is no longer limited only to the documentation of the past, nor is it seen solely as a tool for the detection of nonconformity. Nowadays, the most important quality inspection function is prevention, whose most important goal is to make it before nonconformity. What is expected from modern quality inspection is that it actively improves the production and quality as well as reduces the costs. The aim of the article is to present requirements, guidelines and challenges in the organization of modern quality inspection in a manufacturing company. The role of quality inspection in the classical model and modern model of quality improvement was presented. Determinants of effective quality inspection were presented, as well. The quality inspection methods that best fit into the paradigm of modern quality inspection, that is source inspection, together with visual management were pointed out.

KEYWORDS

control, quality inspection, effectiveness, improvement, challenges.

\section{Introduction. \\ Traditional and new approaches to quality inspection}

The role of quality inspection in the classical model of quality improvement

The basis of the traditional system of quality improvement is a cycle of successive operations of planning, doing and checking [1]. In the traditional approach to quality improvement, quality inspection focuses exclusively on the diagnostic findings, that is determining the level of quality requirements fulfillment, and is limited to the post-operative or post-production inspection. In this cycle, the optimal process conditions are determined at the planning stage, then certain actions are carried out on the basis of the plans, and finally, in the inspection phase, the quality is checked. In the case of finding defects, the inspectors give information to the planning de- partment, where, in the next cycle (that is, manufacturing the subsequent batch of products), corrective action is taken in order to improve the process. The cycle of planning, doing and checking does not allow for finding defects and only provides feedback about the creation of defective products [1]. In production practice, the inspection of this type is often acceptance inspection, and its main purpose is to eliminate from the manufacturing process the products (materials, semi-finished products, parts) that do not meet the requirements.

Quality inspection method used in the traditional approach to improve the quality is judgment inspection. This inspection usually takes place at the end of the process or sequence of operations and it detects defects that already exist as well as consists in comparing manufactured products with the specified standard, detecting those that are not compatible with it and rejecting them as scraps [2]. Judgment inspection model was shown in the Fig. 1. 


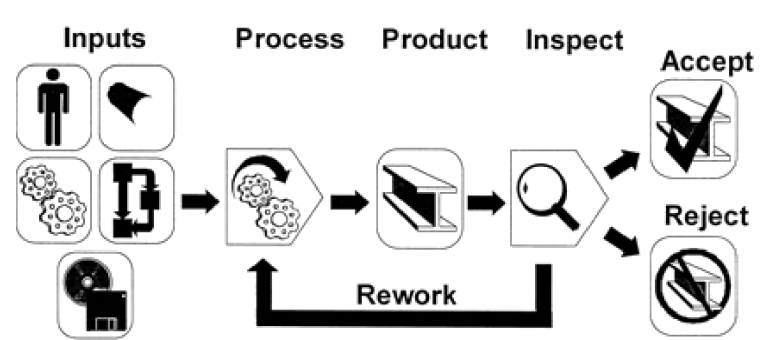

Fig. 1. The operational model of judgment inspection [2].

Judgment inspections are made after a process has transformed inputs into a product. The inputs to each process may include the man, materials, methods, information, and machines as illustrated clockwise at the left of the Fig. 1. Based on inspection, the product is accepted, rejected, or reworked [2]. The traditional model of quality improvement based on the judgment inspection has several drawbacks. Although the judgment inspection prevents sending the defective products to the customer, it does not prevent defects, nor does it provide rapid feedback which would stop the process before producing next defects. Every quality inspection system based on the detection of poor quality by postoperative or postproduction inspection is unreliable, expensive, wasteful and uneconomical. The inspection should be an active tool to prevent the emergence of nonconformity between the desired and the actual state of the process [3]. These requirements are met by the inspection exercised within a modern model of quality improvement.

The role of quality inspection in the modern model of quality improvement

Quality inspection within the context of modern model of quality improvement takes place in the same place where defects and quality problems occur. The combination of operating steps and inspection allows for checking the process conditions before starting the processing, which enables obtaining immediate feedback and helps to solve quality problems before any defective products appear [1]. The location of the quality inspection in the context of a modern model of quality improvement is shown in Fig. 2.
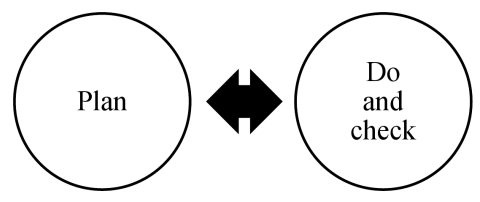

- Check is carried out at source (in a place where mistakes are made).

- Check is combined with the action.

Fig. 2. Linking the do and check steps in the modern system of quality improvement [1].
In the modern approach to improve quality, the quality inspection is treated as a tool of co-creation of value added which, by proposing enhancements and improvements, leads to positive changes in the given area of production. The object of interest of modern quality inspection are the so-called constructive arrangements. These arrangements take the form of conclusions and recommendations resulting from the inspection. The end goal of "such" quality inspection is to improve the quality and efficiency of business by removing irregularities in processes and products, their causes and sources and to stimulate improvement activities by giving examples of proper operation or modification of the existing standards and procedures. The model of modern quality inspection co-creating value added is shown in Fig. 3.

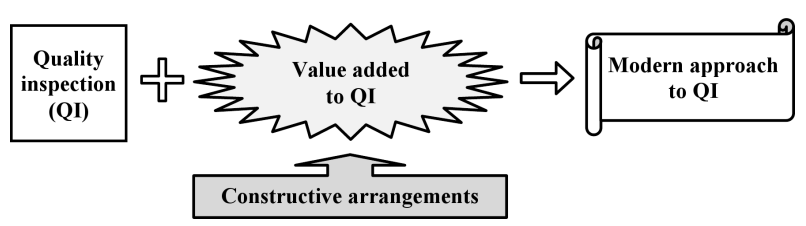

Fig. 3. Model of modern quality inspection co-creating value added.

Modern production requires a modern, fast and accurate quality inspection resulting in cost reduction by decreasing the amount of nonconformity and improving process efficiency. In the modern model of quality improvement, the need to shift focus from quality inspection in a passive form (an ex-post type) towards active quality inspection (an ex-ante type), from event inspection towards anticipative inspection and from results inspection towards process inspection is highlighted. The limitation of quality improvement to the final inspection was characteristic of the traditional model of quality inspection. In the modern model of quality improvement, cause and effect analysis is performed in terms of defects emergence (and not just the analysis of their effects, that is nonconformities or defects) and the best methods of quality inspection are defined for them. Colonel Roman Polko, a former commander of polish Special Forces Unit called GROM, argued: "let us not look for the guilty, let us look for the reasons to eliminate them for the future. It is the only principle of effective action" [4]. This principle has become important for modern quality inspection.

In the industrial enterprise managed in a modern way, quality inspection is an essential source of feedback on the production process, which allows to improve production and reduce the costs [5].

An example of inspection which fits well with a modern model of quality improvement is source in- 
spection. The model of operation of source inspection is shown in Fig. 4.

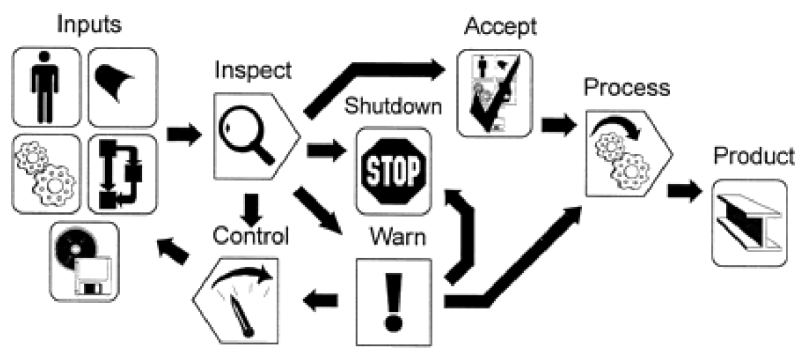

Fig. 4. The operational model of source inspection [2].

Source inspections verify that all of the inputs to a process are acceptable before the process is executed. If any of the inputs are not correct or if any mistakes have been made in the setup, action to stop, warn, or control the inputs is taken before the process is executed. When the inputs are accepted, the process is executed without the need for downstream inspection [2]. The source inspection based on Poka-Yoke solution usage is considered the best method for controlling the variability, defects and other source causes of defects. It is part of a system referred to as ZQC, whose goal is to achieve zero defective products [6]. The inspection of this type is considered by the automotive industry as the most effective method to detect nonconformity and its causes [7]. At the same time, it should be noted that its primary purpose is not so much the detection but preventing nonconformities (preventive method) by identifying and eliminating the causes [8, 9].

The quality inspection methods found in the modern model of quality improvement was shown in Fig. 5 .

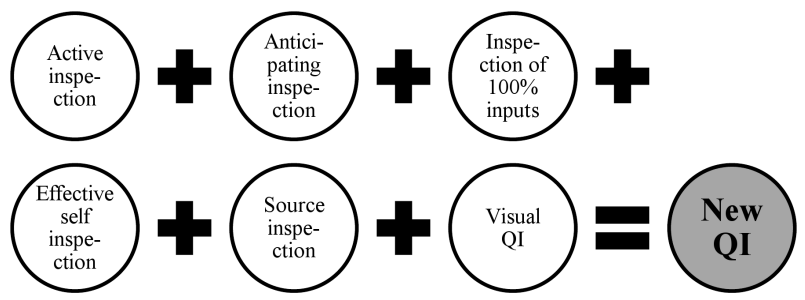

Fig. 5. Statement of modern quality inspection methods.

\section{Conditions of effective quality inspection}

H. Konntz and C. O'Donnell, R.W. Griffin and J.A.F. Stoner and Ch. Wankel, management theorists, formulated the requirements to be met by effective (excellent) control [10]. These requirements are summarized and compared in Table 1.

Table 1

Elements of effective (excellent) control.

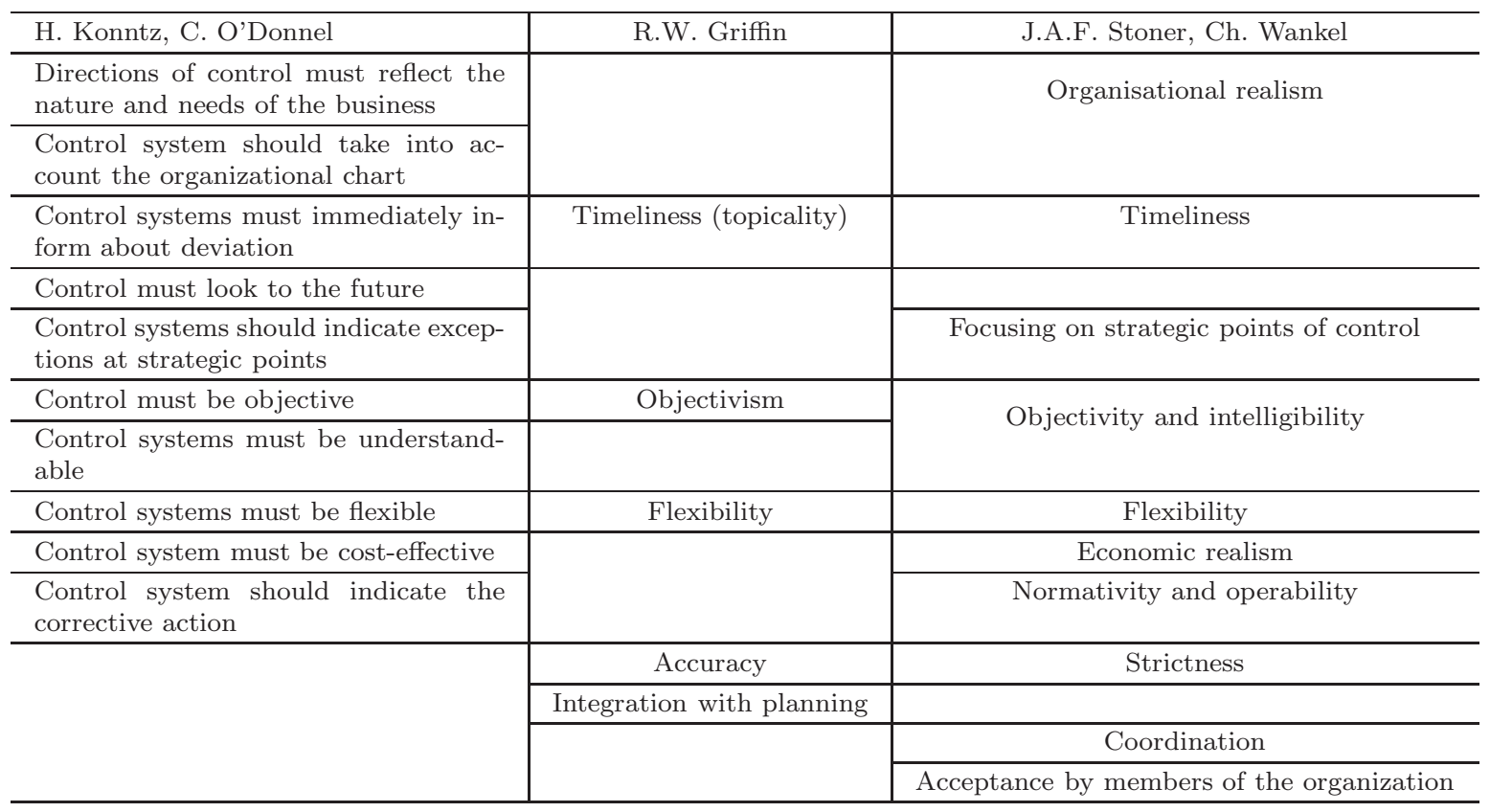


The analysis of the requirements for effective control shows that effective control is one that is:

1. Accurate.

2. Current.

3. Objective.

4. Precise.

5. Anticipative and indicative of the corrective action.

6. Flexible.

7. Focused on the core areas of the organization and linked to the objectives of the organization.

8. Transparent.

9. Acceptable by its staff.

10. Economical.

Based on the requirements for effective control, a set of requirements was developed for effective quality inspection. The results of the conducted quality inspection based on a model of effective control should be used to improve processes, products and the entire organization.

\section{Challenges for quality inspection}

\section{Organizational realism}

Quality inspection system should be in line with organizational realities in the enterprise [11]. Organizational realism of quality inspection system should be understood as the ability to operate smoothly within a given production system taking into account the environmental impact of the production system on the inspection system and the impact of the inspection system on the production system. Organizational realism of quality inspection system requires the application of appropriate quality inspection methods to assess the compliance of specific characteristics of the product with the requirements, taking into account the importance of these characteristics. The quality inspection employees must recognize the link between their involvement and the obtained effects. In every company, the condition of an efficient system of quality inspection is taking into account also the organizational culture in its designing.

\section{Anticipation and prevention is better than only detection}

The priority function of modern quality inspection is prevention, and the most important principle - making it before the defect. The value of modern quality inspection should be measured not only by the number of nonconformities detected, but also the scale of preventive actions, that is the number of nonconformities which have not occurred because of the effective quality inspection. A modern quality inspection system, same as the system of the fighter aircraft (Fig. 6), should not be limited only to actions concerning events that already occurred (defects and nonconformities), but should enable the anticipation of events and indication of potential problems before they really occur [12]. Modern quality inspection should prevent defects rather than just find them. It is also important to determine the significance of the emerging defects [1].

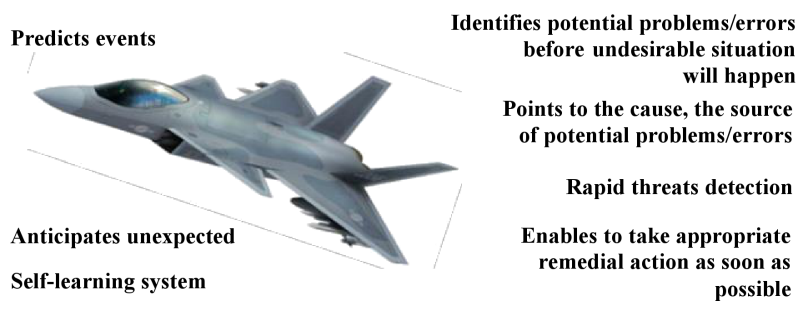

Fig. 6. Aircraft fighter systems as a synonym of modern quality inspection.

Traditionally operating production companies base their activities on a variety of quality inspection methods, with a focus on passive inspection methods. In the leading Japanese companies, the emphasis is put on safety inspection and design of systems resistant to "stupid" defects [13].

The use of such a quality inspection method which would predict the defects and problems within time that would enable the application of corrective measures before producing the nonconforming product should be strived for. It results from the fact that every manager wants to know the future with a probability of 60 or $70 \%$ than know the past with a probability of $100 \%$ [10].

\section{Indication for correction and corrective actions}

Properly developed quality inspection system should detect where defects or nonconformities occur, identify who is responsible for it and determine what needs to be done in this situation (description of correction and corrective actions). The inclusion of a prevention plan in the inspection plan and the practical application of the provisions of the inspection plan in this regard is the zero stage in the process to meet this requirement. Describing the correction by individuals closely associated with the process (operators, production leaders), corrective actions and the use of guidelines in this area in practice are required. 


\section{Active interaction}

\section{- co-creation of value added}

Quality inspection is the process that does not create "added value" to the product [14] does not change the course of production, however, it consumes time, energy, human labor, tools, equipment and surface [15], as well as it has a fundamental drawback, which is the production rate inhibition (it may constitute a "bottleneck" in the process) [16].

Modern quality inspection takes on the task of active impacting technological processes (controlling the quality of these processes) in the direction of preventing the emergence of deviations from established requirements for properties of the products. An important task of quality inspection authorities in this regard is to take effective corrective and preventive actions in order to eliminate the possibility of (repeated) emergence of nonconformity of the product.

Quality inspection should be an important element of the co-creation of value added by proposing enhancements and improvements for processes or products. Quality inspection services should be actively involved in proposing and taking preventive and improvement actions. These actions should be effective, though. As a result of implementation of these actions, the risk of the emergence of nonconformity should be reduced. In addition to reactive activities (characteristic of the traditional model of quality improvement), also participation in the pro-active activities is increasingly expected from the quality inspection. Where others see obstacles, the quality inspection (its services) should see the possibilities. Quality inspection services should deal with "designing the future", that is foreseeing potential problems in order to avoid them or seeking new business opportunities in order to implement them.

\section{The sooner the better}

The quality inspection process, in terms of time and place, should form a unity with the technological process. The inspection should be carried out as close to the place where the inspected property of the product is shaped as possible, preferably on-line [17]. The combination of operating steps and inspection allows for checking the conditions before starting the processing, which enables obtaining immediate feedback and solving the problem before any defective products appear.

The problems related to the quality of the process or product should be detected as early as possible, preferably at the source of their creation. The later the problem or error (or its effect, that is nonconfor- mity) is detected, the greater the cost it generates for the company. The cost of removing the effects caused by a defect in the product increases rapidly together with the number of stages of the production process, starting from the creation of the defect and a stage of its detection.

Figure 7 shows the relationship between efforts for the quality inspection and the cost of detecting defects. The greater the efforts for the quality inspection in the early stages of the production cycle, the less the costs borne by the company due to the detection of nonconformity. This relationship is also to be understood in such a way that the earlier the action aimed at assuring quality is taken (better design, appropriate technologies), the smaller the need for investment in the inspection system. At the same time, the greater the chance of reducing the main component of quality costs - the costs of nonconformity [18].

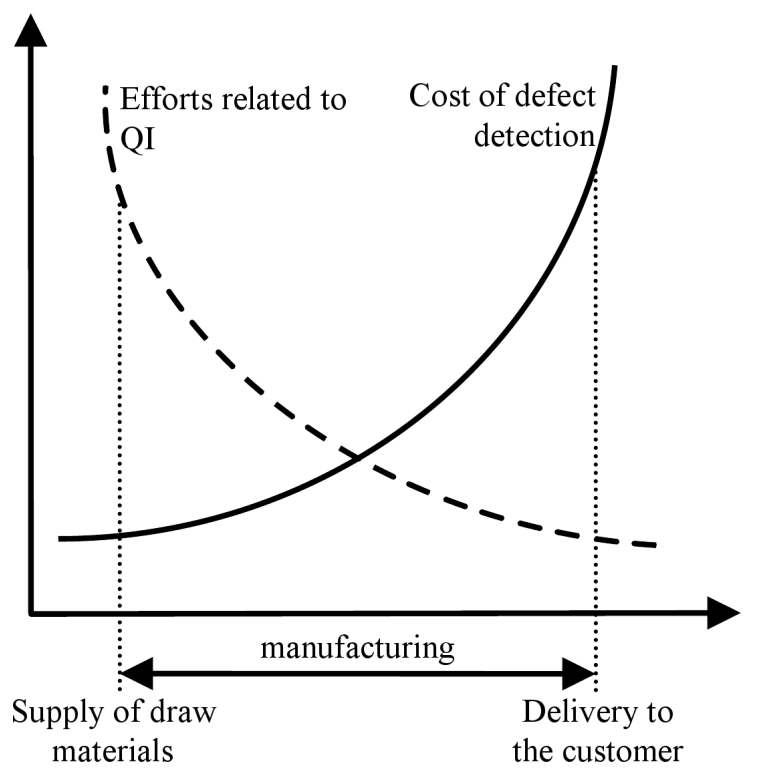

Progress of production process

Fig. 7. A cost of defect detection and efforts put into quality inspection [10].

\section{Focusing on the critical points of the process} and the product characteristics

Quality inspection should be targeted at critical points of the process and product [16]. Quality inspection not only must focus on the deviations from every standard, but should primarily point to those that are essential within customer requirements (critical features of the product and process). Some deviations from the norms or standards of quality are of minor importance, while others are very important. Quality inspection services must identify the 
specific characteristics of the product and the critical points of the process as well as manage them effectively. Quality inspection system should focus, in particular, on those stages in the process where there is the greatest risk for the customer and the greatest likelihood of the emergence of nonconformity. The inspection, in particular, in these stages of the process and with regard to such characteristics of the product, must be effective.

\section{Do it right the first time}

The aim of the concept of Six Sigma, aimed, among others, to reduce the costs of poor quality is to "make good things well from the beginning" [19]. The aim of modern quality inspection should be evaluating product quality or evaluating process stability well from the beginning, that is without errors (socalled $\mathrm{I}^{\mathrm{st}}$ type and $\mathrm{II}^{\text {nd }}$ type errors).

It should be noted that every inspection has two main phases: measurement and evaluation. In both phases, errors may occur. In the first, measurement error may occur - the result is different from the actual measured value. In the second phase, an evaluation error can occur, which is based on the evaluation nonconforming with the actual state - something that meets the requirements is evaluated as nonconforming or vice versa [16]. Errors in the evaluation of nonconformity of given values with the requirements are of two types and are called $\mathrm{I}^{\text {st }}$ type and $\mathrm{II}^{\text {nd }}$ type errors. $\mathrm{I}^{\text {st }}$ type errors involve a recognition of the state of the process or product that meets the requirements as nonconforming, whereas $\mathrm{II}^{\text {nd }}$ type error is a recognition of the state of the process or the product that does not meet the requirements as stable/conforming. The consequence of $\mathrm{I}^{\text {st }}$ type errors is stopping the properly operating (stable) process or destruction (damaging) of the conforming product. In turn, more dangerous are $\mathrm{II}^{\text {nd }}$ type errors, the result of which is failure to stop the unstable process or transferring the nonconforming product to the customer [20]. To evaluate the effectiveness of the quality inspection process in terms of $\mathrm{I}^{\text {st }}$ and $\mathrm{II}^{\text {nd }}$ type errors, indicators presented in certain works can be applied [21].

To ensure high efficiency in the proper evaluation of the product or process from the outset, employees must be trained, they must have adequate knowledge of the correct evaluation of conformity of the product and the detection of nonconformity, the inspection bench must meet the conditions for effective detection of nonconformity (ergonomics) [22], in turn, the standards (instructions) on the basis of which the inspection is carried out must be uniform, clear, precise and acceptable by all inspectors.

\section{Self-inspection}

The modern methods of quality inspection include self-inspection, even though the very idea of self-inspection is not new [23]. The main advantage of self-inspection is the detection of defects at their source and their immediate liquidation. No (quality) inspection subsystem has similar advantages. It is considered a sort of ideal type (form) of (quality) inspection [10]. Among the many techniques that allow for better detection of defective components, selfinspection is considered to be the most effective [24]. Effective self-inspection should replace the need for a multi-stage inspection which is conducted in traditional quality inspection (TQI) (Fig. 8).

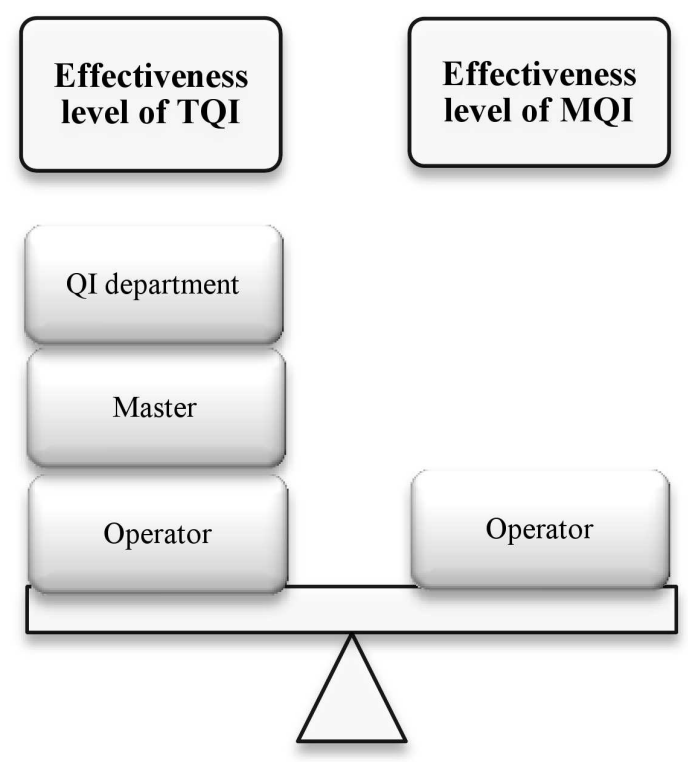

Fig. 8. Self-inspection without verification as a challenge for modern quality inspection (MQI).

\section{Automation}

Modern quality inspection is inexorably heading towards automation and less and less human intervention in the inspection processes. Hiring people for the inspection work is economically unjustified. They should deal with the conceptual work and the robots should be used for inspection work [23]. The complete elimination of the human factor from the quality inspection process by using, for instance, inspection machines or sorting machines, will help to minimize inspection errors [25]. It is postulated to fully automate the inspection process by means of sensors that can offer a high level of processing reliability and at the same time are cost-effective and easy to use [26]. In the quality inspection, increasingly important become quality inspection systems based on machine vision, which allow for process- 
ing and executing multiple inspections simultaneously, which significantly shortens the inspection cycle. Independent, autonomous and self-adapting production requires strong and reliable equipment and well-developed machine vision which would allow for adaptation to rapidly changing production conditions [27]. High speed quality inspection (up to several analyzes per second), the ability to work 24 hours a day, reaching $100 \%$ correctness, makes this type of solution minimize unnecessary costs as a consequence of produce and sell a product that does not meet posed requirements [28].

\section{Cooperation and coordination}

In the company managed in a modern way, everyone works towards improving product quality and customer satisfaction and nobody blames others for the errors, everyone looks for the solutions to current problems of quality, instead. It is important that employees of all departments within a manufacturing company, and, in particular, the production, quality inspection and complaints department worked together as a coherent, flexible and supportive team [16] (Fig. 9). Only through such cooperation, products that fully meet the requirements of customers are formed, and the inspection is economically sound.

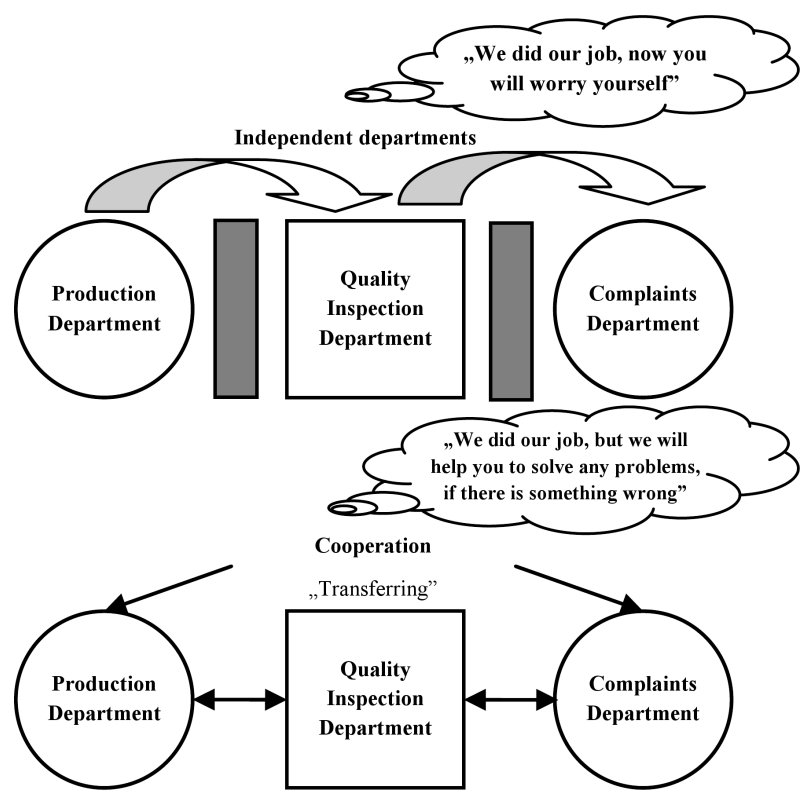

Fig. 9. Cooperation and its lack between production, quality inspection and complaints department.

An important aspect of this cooperation is to coordinate quality inspection information among the departments of the organization. This is important for two reasons. First, each stage of the process may affect the quality of the final product. Second, the information resulting from the inspection should reach all people who need it.

\section{Accuracy, relevance and timeliness of information}

Quality inspection systems must be designed in such a way as to ensure accuracy, relevance and timeliness of the information used and provided. The status of all documents related to the process of quality inspection should be always up to date. Inaccurate data or information based on which quality inspection services operate can result in taking the wrong action that either does not solve the problem or creates a problem where it did not exist. Lack of information where it is needed, or incorrect, outdated and inaccurate information is the enemy of effective quality inspection, hence there is the need for careful inspection planning [16].

Information about the quality of the product/process should be provided as often as necessary or as required by the nature of the inspected properties of the product/process. The more variable the conditions under which quality is created (human, machine, material, environment), the more often the quality inspection should be; when the process is more stable, the quality inspection can be performed less frequently. In any case, the information about the quality of the product/process must be collected, transmitted and evaluated quickly, so that the appropriate corrective action can be taken.

\section{Objectivity, clarity and transparency of quality inspection through visual management}

Quality inspection system should benefit from as objective information as possible about the current status of the inspection and provide it to the interested. All interested parties (not only the quality inspection staff) should have quick and easy access to this information and the information should be communicated in a friendly and intelligible form for those people, always and everywhere.

Help for the people managing the process of quality inspection in this area constitutes visual control in the sense of visual management, which is a result of the success of Toyota and many other companies in the effective implementation of this concept of management [29]. Visual management is, in short, a way to manage workplace, where a significant share comprise visual aids whose task is to streamline the processes and make them run more efficiently and effectively by making the steps in that process more visible. Visual management can be used successfully 
to manage the process of quality inspection to ensure its transparency as well as access to current information by all people interested at anytime and anywhere. The use of visual approach in quality inspection is manifested by the use of different kinds of visual tools, be it the documentation prepared on the basis of visuals, first good product as a visual standard (on the basis of which inspectors assess the conformity with requirements), information boards, or Andon system informing about irregularities in the process or product quality [11].

The principle of using a visual approach in product quality inspection is shown in Fig. 10.

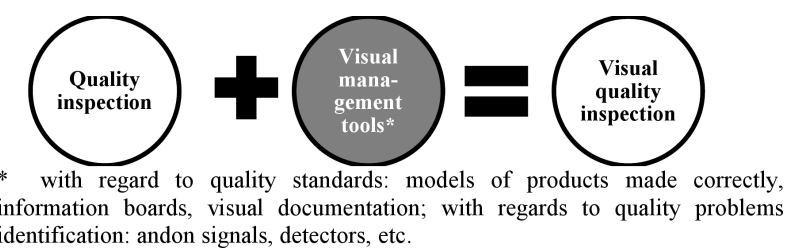
identification: andon signals, detectors, etc.

Fig. 10. Visual management of the quality inspection.

\section{Integration with planning}

The first function of business management is planning, which includes all levels of production organization. Planning is based on an optimal development of work time and resources [30]. Quality inspection should be carefully planned [16]. The role of planning in the modern process of quality inspection has increased because planning reduces the need for precise quality inspection [13]. When all raw materials are properly prepared, instructions are clear, equipment is adequate, and so on, the dependence of the quality on supervision and inspection is limited. Figure 11 shows the difference between conventional ratio of investment in planning and inspection and the same ratio in major Japanese companies.

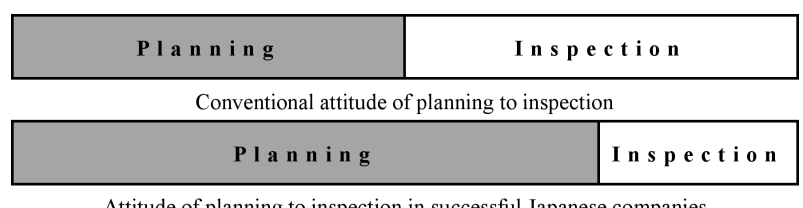

Fig. 11. The conventional attitude to planning and control, and the attitude to planning and control in successful Japanese companies [13].

Planning is not only good for the quality and reducing the direct costs of deffects, but it also brings savings resulting from the employment of fewer inspectors and supervision staff [13]. Planning inspection processes is an essential component of optimization of production costs.
Planning and quality inspection processes start to be considered as a whole. There is a modern method underlining the link among quality, planning and quality inspection referred to as quality controlling. It is a method relating to quality management enabling taking appropriate decisions in this area of the business. Its tasks include assisting in the processes of planning, quality inspection and quality controlling (through participation in these processes), their coordination, as well as supervision and monitoring of the proper course [5].

It should be emphasized that the quality inspection, from the definition, means evaluating the existing cases, and thus something that already happened. The greater the dynamics of the managed events, the more stressed the need to focus on the action planning phase of and their results.

The most important manifestation of the effective integration of planning and quality inspection is the implementation of the provisions of the inspection plan. The inspection plans are a prerequisite for the existence and conduct of quality inspection in the enterprise, and the task of quality inspection services is to ensure their execution. What results from this is that quality inspection methods used in practice must be a reflection of developed inspection plans.

\section{Coexistence with the organization's goals and objectives acceptance by their contractors}

The aim of the modern quality inspection system is to help in achieving the primary objective of the functioning of any organization, that is profit, which, in turn, should be achieved by meeting and/or exceeding the customer requirements by a product quality level [25]. An effective and efficient enterprise production system requires first and foremost effective and efficient manufacturing processes, including an effective and efficient quality inspection. Through the efficient and effective quality inspection process, companies are able to minimize the risk of releasing to the market products not conforming with the requirements of customers (Fig. 12).

Quality inspection must be associated with valid objectives acceptable by all the people whom these objectives concern. The formulated objectives for quality inspection should be a reflection of the objectives contained in the company's quality policy. The objectives of the quality inspection should be developed in accordance with SMART principle, so that they are easy to measure, analyze, evaluate and improve [31]. The objectives must be measurable, achievable and ambitious, real and timed. It is important that, after their establishment, they are com- 
municated to all those whom these objectives concern [32].

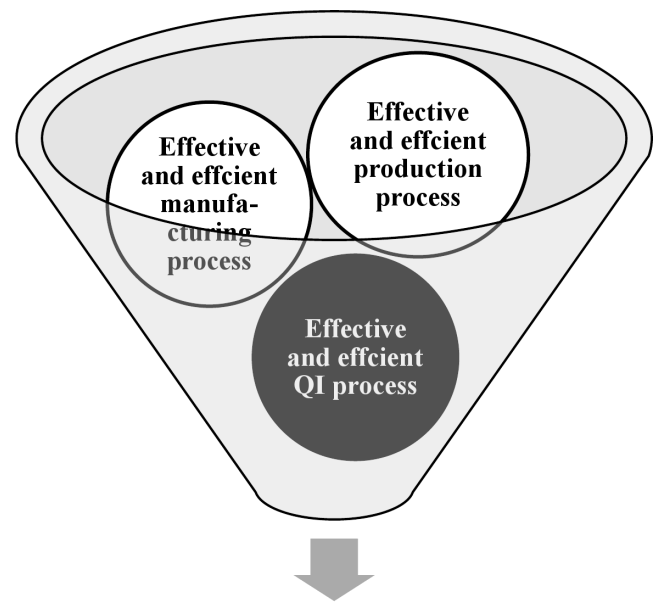

Fulfilling or exceeding the costumer needs and requirements in effective and efficient way

Fig. 12. Quality inspection as a tool to achieve the target - fulfilling or exceeding the customer expectations.

\section{Flexibility}

Quality inspection should keep pace with changes in production systems. Inspection systems must be flexible and their data should be easily used anywhere and anytime to evaluate and inspect the process [33]. Quality inspection must be of such a type that it can be used in conditions of changing plans, unforeseen circumstances or occurring defects. Flexibility in quality inspection can be achieved by developing specific inspection plans taking into account various likely scenarios (prevention plan). An important aspect of quality inspection flexibility is fast update of the inspection plan in the event of changes in the characteristics of the product/process, inspection methods or characteristics of the measurement system. If something is incorrect in the inspection plan, it is important to quickly change it.

\section{Above all well and quickly}

Every customer who buys a product wants to get a "good" product "fast" and at the "cheapest" price. The requirements of "good", "fast" and "cheap" product, which are the basic requirements for the product, should also become the basic requirements for processes in which these products are produced, that is also for quality inspection processes that are part of the manufacturing process. An efficient manufacturing process is the one in which quality goals are achieved efficiently and effectively, time-limits are respected and economically justified costs are borne [16]. Quality inspection can significantly drive (or inhibit) the process of meeting these three basic needs. A "good", "fast" and "cheap" quality inspection determines the "good", "fast" and "cheap" manufacturing process, which in turn creates a "good", "fast" and "cheap" product. When taking measures to systematically improve manufacturing processes, continual improvement and enhancement of the effectiveness of inspection processes should not be forgotten [18].

One of the rules says that the production can not meet all the criteria of cheap, fast and well. Among these three: good, cheap and fast, a combination of two things is possible to provide for. Within quality inspection, by far the most important customer need is the quality (the criterion of "good"), this criterion should be unchanged in this case. The second place in the ranking of significance of the criteria is occupied by the criterion of "fast" - quality inspection might affect the length of the production cycle and constitute a restriction for the speed of the process (it may be the so-called "bottleneck" of the process), in particular, if it is "embedded" in the process (lines). In turn, a cheap inspection, within the meaning of the customer, is an effective inspection, that is the inspection from which the "benefits" (expressed financially) are greater than expenditures incurred on its use. If the cost of the inspection is greater than, for instance, the cost of defects that are detected within the inspection, this inspection becomes ineffective. The effectiveness of quality inspection processes should be ensured.

\section{Economy}

Quality inspection must be worth its cost. The cost of implementing a quality inspection system should be smaller than its benefits, and at most equal [34]. The methods and quality inspection measures must always be chosen taking into account their cost (inspection, repairable and non-repairable defects and complaints), and usefulness of the inspection results. Too many inspections can be costly for the company [35].

There is an optimal level of expenditure on inspections. Better and more effective inspection requires incurring higher costs, but also helps to reduce the level of nonconformity, and therefore the cost of nonconformity. After exceeding a certain level of expenditure on the inspection, its effectiveness is not growing proportionally and benefits of the inspection are getting smaller. In an extreme case, the increase of expenditure on inspection can result in the opposite of the intended effect and reduce the effectiveness of the system of quality evaluation [18]. 
The cost of the system of quality inspection should be lowered through actions within the lean field (identification of waste and its reduction or complete elimination) and Six Sigma projects (cost reduction of erroneous actions, that is $\mathrm{I}^{\text {st }}$ and $\mathrm{II}^{\text {nd }}$ type errors in order to adapt the quality inspection to customer requirements).

\section{Conclusions}

The aim of the article was to present requirements, guidelines and challenges faced modern quality inspection in manufacturing companies. Based on the elements of the effective (excellent) control, which were distinguished by management theorists (H. Konntz, C. O'Donnell, R.W. Griffin, J.A.F. Stoner, Ch. Wankel), the identification of requirements for systems, processes, quality inspection services was carried out. The article is a review of the literature of the subject in aim to identify the elements of the modern quality inspection. Specified requirements, guidelines and challenges for quality inspection, according to the authors, should be the basis for the assessment of systems, processes and quality inspection services. That evaluation should determine whether and to what extent "your" quality inspection system complies with these requirements. Every quality inspection department in every manufacturing company should have developed a kind of „dashboard", which contains a set of tools (indicators, metrics) for quality inspection assessment which will evaluate and monitor the degree of reaching the targets.

A strong competition upon the market results in the fact that the quality is the main advantage in winning new sales markets. Any negligence at the successive stages of production affects the quality of the final product [36]. Low level of quality is one of the most visible indicators of efficiency of the supply chain [37]. Therefore, a strong emphasis should be put on the control of the whole process. The quality inspection system must be effective and efficient. It should be corresponded to requirements of customers quality inspection [38]. To sum up, the modern quality inspection faces tasks that require:

- organisational realism,

- identifying potential errors before the nonconforming product appears,

- cause and effect analysis of the appearing defects,

- active influence on technological processes (controlling the quality of these processes) in order of preventing the appearing of deviation from established requirements for properties of the products.
- efficient detection of defects, determining their causes and deleting or identifying ways to remove these causes,

- ensuring that not any defective product will leave the manufacturing plant (will be delivered to external clients), and that no defective product is produced and transferred to another workstation (to the next internal customer) during the manufacturing process of the product,

- recognizing the significant changes in the production conditions and the reasons causing their adverse effect on the characteristics of the product, what may cause the defects formation,

- indicating the corrective action and enabling taking preventive action as soon as possible at the error occurrence (through the use of visual control),

- taking effective corrective and preventive actions (zero defects repetition of the same kind in product due to the same cause),

- unity of inspection and technological process in terms of space and time,

- concentration of activities on the critical points in the process and the critical properties of the product,

- good product quality evaluation or process stability evaluation from the beginning,

- inspection of $100 \%$ factors affecting the quality of the product $(6 \mathrm{M} \& \mathrm{E})$ before and in the course of the manufacturing process,

- automation and less and smaller human intervention in the inspection process,

- active participation of all those involved in the matters of quality and its inspection in the production hall (in line with the statement: "quality can never be controlled too much")

- active cooperation and collaboration in quality problem solving and improvement activities between departments in the enterprise,

- accuracy, relevance and timeliness of received and transmitted information,

- greater participation of visual tools (visual control) to manage the production process and quality inspection,

- greater integration of planning,

- coexistence with the objectives of the organization and ensuring the acceptance of these objectives by their contractors,

- flexibility,

- concentration on critical customer requirements for a "good" and "fast" product,

- less labor and capital intensity of inspection processes. 
Nothing is so perfect that it could not be improved. At the end it is worth noting that there is no perfect quality inspection system, even the most effictive of its form, which is rather the quality assurance system source inspection/mistake proofing supported by visual management tools) does not guarantee that the nonconforming product will not be produced and will not be delivered to the customer. This does not mean, however, that quality inspection should not be improved and that it should not be getting better, more efficient and more effective.

\section{References}

[1] Kubik Sz. [Ed.], Mistake-Proofing for Operators: The ZQC System [in Polish: Zapobieganie btędom dla Operatorów: System ZQC], Wroclaw, ProdPublishing.com, 2010.

[2] Hinckley C.M., Defining the best quality-control systems by design and inspection, Clinical Chemistry, 5, 873-879, 1997.

[3] Muhlemann A.P., Oakland J.S., Lockyer K.G., Management - production and services [in Polish: Zarzadzanie - produkcja $i$ ustugi], Warsaw, PWN, 2001.

[4] Blikle A., The quality doctrine. The thing about the effective management [in Polish: Doktryna jakości - rzecz o skutecznym zarzadzaniu], Gliwice, Helion, 2014.

[5] Bieńkowska A., Kral Z., Quality controlling as a modern method of support and quality coordination [in Polish], Problemy Jakości, 10, 7-13, 1998.

[6] Shingo S., Kaizen and the art of creative thinkingthe scientific thinking mechanism, Bellingham, WA, Enna Products Corporation and PCS Inc., 2007.

[7] Greber T., Inspection and control in the risk analysis in accordance with the FMEA method [in Polish: Kontrola $i$ sterowanie $w$ analizie ryzyka zgodnie z metoda FMEA], Zarządzanie Jakością, 1, p. 23, 2011.

[8] Hinckley C.M., Make no mistake - an outcome based approach to mistake-proofing, Portland, Productivity Press, 2001.

[9] Hinckley C.M., Make no mistake - errors can be controlled, Quality \& Safety in Health Care, 12, 359365, 2003.

[10] Kuc B.R., Control as a function of management [in Polish: Kontrola jako funkcja zarzadzania], Warsaw, Difin, 2009.

[11] Podsadowski M., Organization of quality control department [in Polish: Organizacja dziatu kontorli jakości], Materiały szkoleniowe, Cracow, TQM Soft, 2010.

[12] Herod M., Weight control in a line (checkweigher) and net weight control [in Polish: Kontrola wagi w linii (Checkweigher) a kontrola wagi netto], Ważenie. Dozowanie. Pakowanie, 3, 53, 2007.

[13] Drummond H., In the pursuit of quality: Total quality management [in Polish: $W$ pogoni za jakościa: Total quality management], Warsaw, Wolters Kluwer S.A., 1998.

[14] Czerska J., Improving the value stream [in Polish: Doskonalenie strumienia wartości], Warsaw, Difin, 2009.

[15] Durlik I., Engineering of management [in Polish: Inżnieria zarzadzania], Warsaw, PLACET, 2015.

[16] Czyżewski B., Internal quality inspection in a manufacturing company [in Polish: Wewnętrzna kontrola jakości w przedsiębiorstwie produkcyjnym], Poznan, Wielkopolski Klub Jakości FSNT NOT, 2006.

[17] Hamrol A., Policies and practices of efficient operation [in Polish: Strategie i praktyki sprawnego działania], Warsaw, PWN, 2015.

[18] Bożek M., Hamrol A., Rogalewicz M., Analysis of inspection cost in the manufacture of medical devices - a case study [in Polish: Analiza kosztów kontroli w produkcji wyrobów medycznych - studium przypadku], XVII Conference Innovation in Management and Production Engineering, 2nd Tome, Zakopane, 2014.

[19] Eckes G., The Six Sigma Revolution: How General Electric and Others Turned Process Into Profits [in Polish: Rewolucja Six Sigma: Jak General Electric $i$ inne przedsiębiorstwa zmienity proces $w$ zyski], Warsaw, MT Biznes, 2010.

[20] Borkowski S., Knop K., Mielczarek K., The Use of Six Sigma indicators for Measurement the Process Quality of Products' Conformity Assessment in the Alternative Control, Chapter 8, [in:] Quality Control as Process Improvement Factor, S. Borkowski, M. Konstanciak [Eds.], SMJiP, Częstochowa, pp. 116-131, 2012.

[21] Rewilak J., MSA for attributes [in Polish: MSA dla kontorli alternatywnej], Materiały szkoleniowe, Cracow: TQMSoft, 2012.

[22] Wachowiak F., Kujawińska A., Influence of selected ergonomic factors on the effectiveness of quality control [in Polish: Wplyw wybranych czynników ergonomicznych na skuteczność kontroli jakości], Inżynieria Maszyn, 18, 1, 51-59, 2013.

[23] Kolman R., Guidance for quality inspector [in Polish: Poradnik kontrolera jakości], Bydgoszcz, Ośrodek Postępu Organizacyjnego, 1998. 
[24] Głowacka-Fertsch D., Fertsch M., Production management [in Polish: Zarzadzanie produkcja], Poznan, Wyższa Szkoła Logistyki, 2004.

[25] Webber L., Wallace M., Quality control for dummies, Hoboken, NJ, Wiley Publishing Inc., 2007.

[26] ISRA Vision Systems Inc., 100\% Quality Inspection, Quality Magazine, 5, 2009.

[27] Kwaśniewski M., Machine vision - a new application [in Polish: Widzenie maszynowe - nowe zastosowania], available on:

http://sluzby-ur.pl/artykuly/491/widzenie_maszynowe_nowe_zastosowania.html

[28] Blicharski K., Vision quality control systems as a future of production [in Polish: Systemy wizyjnej kontroli jakości przyszłościa produkcji], Inżynieria \& Utrzymanie Ruchu, 12, 36-40, 2006.

[29] Liker J.K., Toyota Way: 14 Management Principles from the World's Greatest Manufacturer [in Polish: Droga Toyoty - 14 zasad zarzadzania wiodacej firmy produkcyjnej świata], Warsaw, MT Biznes, 2006.

[30] Ulewicz R., Jelonek D., Mazur M., Implementation of logic flow in planning and production control, Management and Production Engineering Review, $7,1,89-94,2016$.

[31] Rakowiec R., How to properly set quality targets [in Polish: Jak prawidłowo wyznaczyć cele jakości], Materiały szkoleniowe, Gdansk, Eniwersytet, 2013.
[32] Reinfuss R., MBO - simple and effective techniques for managing your company [in Polish: $M B O$ - prosta $i$ skuteczna technika zarzadzania Twoja firma], Gliwice, Helion, 2011.

[33] Sloma-Williams T., Five Steps to Cutting Inspection Costs, Quality Magazine, no 4(1), 2003.

[34] Kujan K., The technique and quality control management in mechanical engineering [in Polish: Technika $i$ zarzadzanie kontrola jakości $w$ budowie maszyn], Lublin, Politechnika Lubelska, 2002.

[35] Borkowski S., Ulewicz R., Production management. Production systems [in Polish: Zarzadzanie produkcja. Systemy produkcyjne], Sosnowiec, Humanitas, 2008.

[36] Ulewicz R., Quality control system in production of the castings from spheroid cast iron, Metalurgija, 42, $1,61,2003$.

[37] Nowicka-Skowron M., Ulewicz R., Quality management in logistics processes in metal branch, Metal 2015, 24th International Conference on Metallurgy and Materials, Brno, Czech Republic, JUN 03-05, 1707-1712, 2015.

[38] Knop K., Using the CTQ tree to identify requirements of quality inspection customers [in Polish: Wykorzystanie drzewa CTQ do identyfikacji wymagań klientów kontroli jakości], Zeszyty Naukowe Politechniki Poznańskiej. Organizacja i Zarządzanie, $66,57-73,2015$. 